\title{
Influence of Type of Birth and Sex on Weaning Weight of Dorper Crossbred Lambs
}

\author{
Geraldo Dos Santos Tupinambá ${ }^{1}$, Tiago Neves Pereira Valente ${ }^{2}$, Jeferson Corrêa Ribeiro ${ }^{3}$, \\ Wallacy Barbacena Rosa dos Santos ${ }^{3}$, Andréia Santos Cezário ${ }^{3}$, Erico da Silva Lima ${ }^{4}$, Bruno Borges Deminicis ${ }^{5}$ \\ $\&$ Aline Sousa Camargos ${ }^{3}$ \\ ${ }^{1}$ Agronomist Engineer, Brazil \\ ${ }^{2}$ Instituto Federal Goiano, Posse, Brazil \\ ${ }^{3}$ Instituto Federal Goiano, Morrinhos, Brazil \\ ${ }^{4}$ FMU, São Paulo, SP, Brazil \\ ${ }^{5}$ University of Southern Bahia, Teixeiras de Freitas, BA, Brazil \\ Correspondence: Tiago Neves Pereira Valente, Instituto Federal Goiano, Campus Posse, GO, Rua Correntina, $\mathrm{n}^{\circ}$ \\ 824, Setor Dom Prudêncio, CEP 73900-000, Brazil. Tel: 55-64-981-097-444. E-mail: \\ tiago.valente@ifgoiano.edu.br
}

Received: April 15, 2018

doi:10.5539/jas.v10n7p492
Accepted: May 16, $2018 \quad$ Online Published: June 15, 2018

URL: https://doi.org/10.5539/jas.v10n7p492

The research is financed by IFGoiano, Go, Brazil.

\begin{abstract}
The aim of the present study was to analyze live weight and growth data of live weight at birth to $24.5-25.5 \mathrm{~kg}$ in weaned Dorper crossbred lambs. A total of 93 Dorper crossbred born lambs ( $1 / 2$ Dorper $+1 / 2$ Santa Inês) were evaluated, with percentage of 17.7 double (twin couple $=21 \%$, twin with only females $=50 \%$, twin with only males $29 \%)$. The sex of the lamb influenced $(P<0.05)$ the live weight at birth total $\left(\mathrm{LWB}_{\text {total }}\right)$ and live weight at birth average ( $\mathrm{LWB}_{\text {averagee }}$, the male lambs had in both characteristics superior values. No differences $(P>0.05)$ were found for the age at weaning (AW), live weight at birth total $\left(\mathrm{LWW}_{\text {total }}\right)$ and live weight at weaning average $\left(\mathrm{LWW}_{\text {average }}\right)$. For the type of birth all characteristics were significant $(P<0.05)$. For doubling birth the characteristics $\mathrm{LWB}_{\text {total }}, \mathrm{AW}$ and $\mathrm{LWW}_{\text {total }}$ had higher values
\end{abstract}

Keywords: live weight at birth, sex, type of birth

\section{Introduction}

Lambs that are born heavier have a greater chance of survival (Dwyer, 2003). However, there is an association between higher birth weight and increased sheep calving difficulty, causing dystocia and in some cases is the death of the lamb (Maxa et al., 2014). It is important that lambs can stand up and have udder search behavior since they are born with limited energy reserves and require colostrum immediately after birth to survive (Moraes et al., 2016). A short time to first feeding is desirable because the survival rate is enhanced for the lambs that stand out and quickly ingest milk (Dwyer, 2014). This is due to the fact that lambs with low birth weight have less body reserves; they are less vigorous at lambing; they have a lower body temperature and they take longer to stand up and ingest the colostrum (Vuchkov \& Dimov, 2008; Dwyer, 2008). Factors, such as the type of birth, the sex of the lamb and the age of the ewe at lambing, may affect the require development of lambs (Carneiro et al., 2007). The difference in live weight is largely related to sex and type of birth (Simeonov et al., 2014). During the first 14 days of the suckling period the growth of lambs depended mainly on the amount of suckled milk. The male lambs grew faster than females after weaning. The lambs born as twins or singles placed under the same conditions of feeding and management did not differ in daily growth after weaning. Differences in live weight of lambs at birth and at weaning time were apparent until lambs reached $25 \mathrm{~kg}$ live weight (Barbieri et al., 2014).

The aim of this study is the present study was to analyze live weight and growth data of live weight data at birth until the mark of $24.5-25.5 \mathrm{~kg}$ in weaned Dorper crossbred lambs. 


\section{Method}

\subsection{Experimental Site}

The experiment was conducted in Fazenda Rancho Alegre, Posse city, Góias State, Brazil (average altitude of $811 \mathrm{~m}$, at $14^{\circ} 5^{\prime} 34^{\prime \prime} \mathrm{S}, 46^{\circ} 22^{\prime} 8^{\prime \prime} \mathrm{W}$ ). The climate of the region is classified as type Aw by the Köppen classification, with an average annual rainfall of $1200-1500 \mathrm{~mm}$.

\subsection{Animal Management}

The evaluated a total of 93 Dorper crossbred lambs born (1/2 Dorper + 1/2 Santa Inês), with percentage of 17.7 double (twin couple $=21 \%$, twin with only females $=50 \%$, twin with only males $29 \%$ ), date collected in 2017 .

The ewes were dewormed before calving. The ewes and lambs were kept on Coastcross (Cynodon dactylon) pastures, with free access to mineral salt. The lambs were weaned between 155 to 165 days of age, with 24.5 to $25.5 \mathrm{~kg}$. The live weight was measured without restrict the animals of feed and water, with exception only at the end of the experiments when the lambs were kept $12 \mathrm{~h}$ without water and $24 \mathrm{~h}$ without feed.

Characteristics evaluated:

$\mathrm{LWB}_{\text {total }}=$ Live weight at birth total $(\mathrm{kg})=$ birth weight was considered. Thus, dams who had twins, had birth weights of each lamb added.

$\mathrm{LWB}_{\text {average }}=$ Live weight at birth average $(\mathrm{kg})=$ the mean weights were obtained by the proportion between the total birth weight and the number of lambs.

$\mathrm{AW}=$ Age at weaning (days) $=$ age in days between birth and weaning.

$\mathrm{LWW}_{\text {total }}=$ Live weight at weaning total $(\mathrm{kg})$ = weaning weight was considered. Thus, dams that had twins, had weights of each lamb added together.

$\mathrm{LWW}_{\text {average }}=$ Live weight at weaning average $(\mathrm{kg})=$ the mean weights were obtained by the ratio of the total weaning weight by the number of lambs.

$\mathrm{ADG}=$ Average daily gain $(\mathrm{kg})=$ ratio between mean weaning weight and weaning age.

\subsection{Statistical Analysis}

The data were submitted to the normality test (Shapiro-Wilk, Kolmogorov-Smirnov and Cramer-von Mises). After verifying if the data follow a normal distribution $N\left(\mu, \sigma^{2}\right)$, the results were submitted to Pearson and Spearman correlation analysis.

Pearson correlation coefficient is a measure of the linear correlation between two variables $X$ and $Y$. It has a value between +1 and -1 .

where, $\rho=1$ is total positive linear correlation; $\rho=0$ is no linear correlation; $\rho=-1$ is total negative linear correlation.

$$
\rho=\frac{\sum(x-\bar{x})(y-\bar{y})}{\sqrt{\sum(x-\bar{x})^{2} \sum(y-\bar{y})^{2}}}
$$

The Spearman correlation coefficient is defined as the Pearson correlation coefficient between the ranked variables, according recommendation Daniel (1990).

$$
\rho=1-\frac{6 \sum_{i=1}^{n} d_{i}^{2}}{n^{3}-n}
$$

where, $n$ is the number of pairs $\left(x_{i}, y_{i}\right)$, and $d_{i}=$ (positions of $x_{i}$ between the values of $x$ ) - (positions of $y_{i}$ between the values of $y$ ).

If the positions of $x$ are exactly equal to the positions of $y$, then all $d_{i}$ will be zero and $\rho$ will have value 1 .

The sex and number of animals born at each gestation were considered as fixed effects. Thus, for each ewe, the fixed effects were compared on each analyzed characteristic, using the $t$ test at $5 \%$ probability. All statistical analyzes were submitted to statistical software SAS, 9.0 software (SAS, 2001).

\section{Results}

For the analysis of the Pearson and Spearman correlations it is necessary that the data have a normal distribution. Thus, the tests of Shapiro-Wilks, Kolmogorov-Smirnov and Cramer-von Mises were used. For the characteristics analyzed, only Live weight at birth total $\left(\mathrm{LWB}_{\text {total }}\right)$, Age at weaning (AW) and Live weight at weaning total $\left(\mathrm{LWW}_{\text {total }}\right)$ were not significant $(P>0.001)$ for the Shapiro-Wilks test. For the Kolmogorov-Smirnov and 
Cramer-von Mises tests, all characteristics had normality. Thus, it was considered that all characteristics follow normal distribution (Table 1).

Table 1. Correlations of Pearson (above diagonal) and Spearman (below diagonal) for the characteristics analyzed

\begin{tabular}{lllllll}
\hline Characteristic & LWB total & LWB average & AW & LWW total & LWW average & ADG \\
\hline LWBtotal & & 0.2882 & -0.0502 & 0.8514 & 0.1379 & 0.0649 \\
LWBaverage & 0.4303 & & -0.8466 & -0.2078 & 0.7231 & 0.7629 \\
AW & -0.2363 & -0.8358 & & 0.3539 & -0.7349 & -0.8865 \\
LWWtotal & 0.8228 & 0.2069 & -0.1606 & & -0.1064 & -0.2217 \\
LWWaverage & 0.2750 & 0.7076 & -0.7206 & 0.4766 & & 0.9535 \\
ADG & 0.2100 & 0.7407 & -0.8741 & 0.3688 & 0.9472 & \\
\hline
\end{tabular}

Note. $\mathrm{LWB}_{\text {total }}=$ Live weight at birth total $(\mathrm{kg}) ; \mathrm{LWB}_{\text {average }}=$ Live weight at birth average $(\mathrm{kg}) ; \mathrm{AW}=\mathrm{Age}$ at weaning (days); $\mathrm{LWW}_{\text {total }}=$ Live weight at weaning total $(\mathrm{kg}) ; \mathrm{LWW}_{\text {average }}=$ Live weight at weaning average $(\mathrm{kg}) ; \mathrm{ADG}=$ Average daily gain $(\mathrm{kg})$.

The highest observed value was between average daily gain (ADG) and live weight at weaning average $\left(\mathrm{LWW}_{\text {average }}\right)$ for the correlations of Pearson and Spearman, which implies that animals that had greater $\mathrm{LWW}_{\text {average }}$, had greater ADG gain during the phase of suckling. A negative correlation between age at weaning $(\mathrm{AW}) \times \mathrm{LWW}_{\text {average }}$ and $\mathrm{AW} \times \mathrm{ADG}$. This implies that animals that had lower AW, had higher $\mathrm{LWW}_{\text {average }}$ and higher ADG in the lactation period.

The $\mathrm{LWB}_{\text {total }}$ characteristic obtained higher correlation values only with $\mathrm{LWW}_{\text {total }}$ and low magnitude correlations with the other characteristics. Lambs that had higher $\mathrm{LWB}_{\text {average }}$ had lower AW and higher $\mathrm{LWW}_{\text {average }}$ and ADG.

The sex of the lamb influenced $(P<0.05)$ the $\mathrm{LWB}_{\text {total }}$ and $\mathrm{LWB}_{\text {average }}$, the male lambs had in both characteristics superior values. No differences $(P>0.05)$ were found for the $\mathrm{AW}, \mathrm{LWW}_{\text {total }}$ and $\mathrm{LWW}_{\text {average. }}$

For the type of birth all characteristics were significant $(P<0.05)$. For doubling birth the characteristics $\mathrm{LWB}_{\text {total }}$, $\mathrm{AW}$ and $\mathrm{LWW}_{\text {total }}$ had higher values (Table 2).

Table 2. Means and standard deviation of the characteristics analyzed shared by sex and number of born

\begin{tabular}{llllllll}
\hline Characteristic (Effects) & LWB total & LWB average & AW & LWW total & LWW average & ADG \\
\hline Sex & F & $4.40 \pm 0.13$ & $2.98 \pm 0.11$ & $159.71 *_{ \pm} 1.67$ & $36.98 * \pm 0.40$ & $24.80 *_{ \pm} \pm 0.31$ & $137.39 *_{ \pm} .79$ \\
& $\mathbf{M}$ & $4.83 \pm 0.13$ & $3.38 \pm 0.11$ & $155.29 *_{ \pm} 1.70$ & $37.63 * \pm 0.40$ & $25.47 *_{ \pm} \pm 0.32$ & $143.62 * \pm 2.84$ \\
\hdashline Number of born & $\mathbf{1}$ & $3.48 \pm 0.09$ & $3.48 \pm 0.07$ & $150.50 \pm 1.13$ & $25.92 \pm 0.27$ & $25.92 \pm 0.21$ & $149.93 \pm 1.89$ \\
& $\mathbf{2}$ & $5.75 \pm 0.18$ & $2.87 \pm 0.15$ & $164.50 \pm 2.43$ & $48.69 \pm 0.58$ & $24.34 \pm 0.46$ & $131.09 \pm 4.06$ \\
\hline
\end{tabular}

Note. $\mathrm{LWB}_{\text {total }}=$ Live weight at birth total $(\mathrm{kg}) ; \mathrm{LWB}_{\text {average }}=$ Live weight at birth average $(\mathrm{kg}) ; \mathrm{AW}=$ Age at weaning (days); $\mathrm{LWW}_{\text {total }}=$ Live weight at weaning total $(\mathrm{kg}) ; \mathrm{LWW}_{\text {average }}=$ Live weight at weaning average $(\mathrm{kg}) ; \mathrm{ADG}=$ Average daily gain $(\mathrm{kg})$.

Means followed by * do not differ from each other within the same column, by Student's $\mathrm{t}$ test at $5 \%$ probability.

\section{Discussion}

For type of birth, lambs that had higher $\mathrm{LWB}_{\text {average }}$ had lower AW and higher $\mathrm{LWW}_{\text {average }}$ and ADG. Similar results to the study were found by Koritiaki et al. (2013), the animals from single births presented higher average weight from birth to weaning, as well as of all the measurements from birth to 154 days of age than those from twin births. This feature should be viewed with precaution, because this higher birth weight may be associated with dystocia and in some cases is the death of the lamb (Gardner et al., 2007; Maxa et al., 2014). Theoretically, in all mammalian species, there is an ideal birth weight in which neonatal survival is maximized. The genetic component accounting for some of the variation in birth weight as extremes beyond this range will, over time, be selected out: low birth weight is associated with increased neonatal mortality and high birth weight with complicated labour (dystocia) and maternal death (Gardner, 2007). With different genetic groups, the difference in birth weight was also achieved in weaning weight at 90 days of age (Villarroel et al., 2006). 
Barbieri et al. (2014) examined the effects on lamb weight and survival at weaning from double lambs or singletons lamb born, and concluded that the lambs born from mature sheep were heavier $(P<0.05)$. The weaning weight of lambs born from sheep with twins or singletons did not differ $(P>0.05)$. Lambs born in doubling birth weaned later $23.1 \mathrm{~d}$ (doubling birth) versus $20.6 \mathrm{~d}$ (no doubling birth) (Simeonov et al., 2014). Twins are born smaller than singletons, this has been assumed to be secondary to limited nutrient supply in late gestation. The adult consequences of being conceived a twin, are determined in early gestation (Hancock et al., 2012).

Similar results to this study were found for the lamb gender by Wallace et al. (2014). According to Gardner et al. (2007), the population mean birth weight for male and female lambs was $4.92 \pm 0.01$ and $4.57 \pm 0.01 \mathrm{~kg}$ respectively. Males were, on average, $363 \pm 25 \mathrm{~g}$ larger than female lambs $(P<0.0001)$. Body weight of lambs at birth were almost the same for both sex (3.39 and $3.36 \mathrm{~kg}$ for male and female, but was always observed higher weight for males (Petrovic et al., 2011). An explanation of the greater weight of males at birth may be related to development in the uterus, males appear to grow faster than respective females in the uterus (Loos et al. 2001). The reduced birth weight in twins probably reflects an impaired ability of fetal twin lambs to lay body reserve in preparation for birth. This is probably due to the increases demand two fetuses place on the dams in late gestation, because decreases plasma glucose and increases plasma free fatty acid and $\beta$-hydroxybutyrate concentrations in twin-bearing ewes in late gestation, and decreases plasma concentrations of glucose, insulin and IGF-1 on the first day of life in twin lambs compared with singletons Rumball et al. (2008).

\section{Conclusion}

Dorper crossbred lambs, born from ewes kept on Coastcross (Cynodon dactylon) pastures, that had higher live weight at birth average had lower age at weaning and consequently higher average daily gain.

The sex of the lamb influenced the live weight at birth total and live weight at birth average, the male lambs had in both characteristics superior values.

For type of birth, twins are born smaller than singletons.

\section{References}

Barbieri, I., Montossi, F., Viñoles, C., \& Kenyon P. R. (2014). Effect of shearing ewes during mid- and late-pregnancy on lambs weight at birth and survival to weaning under grazing conditions in Uruguay. Small Ruminant Research, 119, 28-32. https://doi.org/10.1016/j.smallrumres.2014.03.004

Carneiro, P. L. S., Malhado, C. H. M., Santos, F. N. D., Santos, P. F., \& Paiva, S. R. (2007). Desenvolvimento ponderal e diversidade fenotípica entre cruzamentos de ovinos Dorper com raças locais. Pesquisa Agropecuária Brasileira, 42(7), 991-998. https://doi.org/10.1590/S0100-204X2007000700011

Daniel, W. W. (1990). Spearman rank correlation coefficient. Applied Non-parametric Statistics (2nd ed., p. 635). Boston: PWS-Kent.

Dwyer, C. M. (2003). Behavioural development in the neonatal lamb: Effect of maternal and birth-related factors. Theriogenology, 59, 1027-1050.

Dwyer, C. M. (2008). Genetic and physiological effects of maternal behavior and lamb survival. Journal of Animal Science, 86, E246-E258.

Dwyer, C. M. (2014). Maternal behaviour and lamb survival: From neuroendocrinology to practical application. Animal, 8(1), 102-112. https://doi.org/10.1017/S1751731113001614

Gardner, D. S., Buttery, P. J., Daniel, Z., \& Symonds, M. E. (2007). Factors affecting birth weight in sheep: maternal environment. Reproduction, 133, 297-307. https://doi.org/10.1530/REP-06-0042

Hancock, S. N., Oliver, M. H., McLean, C., Jaquiery, A. L., \& Bloomfield, F. H. (2012). Size at birth and adult fat mass in twin sheep are determined in early gestation. J. Physiol., 590, 1273-1285. https://doi.org/ 10.1113/jphysiol.2011.220699

Koritiaki, N. A., Ribeiro, E. L. A., Mizubuti, I. Y., Silva, L. D. F., Barbosa, M. A. A. F., Scerbo, D. C., ... Fernandes Júnior, F. (2013). Effect of environmental factors on performance of purebred and crossbred Santa Inês lambs from birth to 154 days of age. Revista Brasileira de Zootecnia, 42, 87-94. https://doi.org/10.1590/S1516-35982013000200002

Loos, R. J., Derom, C., Eeckels, R., Derom, R., \& Vlietinck, R. (2001). Length of gestation and birth weight in dizygotic twins. Lancet, 358, 560-561. 
Maxa, J., Sharifi, A. R., Pedersen, J., Gauly, M., Simianer, H., \& Norberg, E. (2009). Genetic parameters and factors influencing survival to twenty-four hours after birth in Danish meat sheep breeds. J. Anim. Sci., 87, 1888-1895. https://doi.org/10.2527/jas.2008-1319

Moraes, A. B., Poli, C. H. E. C., Fischer, V., Fajardo, N. M., Aita, M. F., \& Porciuncula, G. C. (2016). Ewe maternal behavior score to estimate lamb survival and performance during lactation. Acta Scientiarum. Animal Sciences, 38, 327-332. https://doi.org/10.4025/actascianimsci.v38i3.29923

Petrovic, M. P., Muslic, D. R., Petrovic, V. C., \& Maksimovic, N. (2011). Influence of environmental factors on birth weight variability of indigenous Serbian breeds of sheep. African Journal of Biotechnology, 10, 4673-4676. https://doi.org/10.5897/AJB10.2189

Rumball, C. W., Harding, J. E., Oliver, M. H., \& Bloomfield, F. H. (2008). Effects of twin pregnancy and periconceptional undernutrition on maternal metabolism, fetal growth and glucose-insulin axis function in ovine pregnancy. J. Physiol., 586, 1399-1411.

SAS (Statistical Analysis System). (2001). User's guide: Statistics. Cary: SAS Institute.

Simeonov, M., Todorov, N., Nedelkov, K., Kirilov, A., \& Harmon, D. L. (2014). Influence of live weight, sex and type of birth on growth and slaughter characteristics in early weaned lambs. Small Ruminant Research, 121, 188-192.

Villarroel, A. B. S., Lima, L. E. S., Oliveira, S. M. P., \& Fernandes, A. A. O. (2006). Weight gain and carcass traits of Texel and Santa Inês crossbred lambs in a semi-intensive husbandry system. Ciênc. Agrotec., 30, 971-976.

Vuchkov, A., \& Dimov, D. (2008). Study on the live weight and growth intensity of the lambs of White Maritsa sheep. J. Anim. Sci., 4, 41-45.

Wallace, J. M., Milne, J. S., Aitken R. P., \& Adam, C. L. (2014). Influence of birth weight and gender on lipid status and adipose tissue gene expression in lambs. Journal of Molecular Endocrinology, 53, $131-144$. https://doi.org/10.1530/JME-14-0123

\section{Abbreviations}

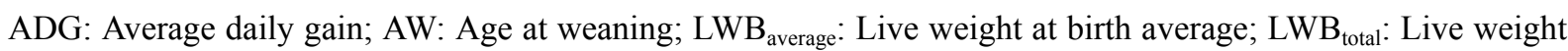
at birth total; $\mathrm{LWW}_{\text {average }}$ : Live weight at weaning average; $\mathrm{LWW}_{\text {total }}$ : Live weight at weaning total.

\section{Copyrights}

Copyright for this article is retained by the author(s), with first publication rights granted to the journal.

This is an open-access article distributed under the terms and conditions of the Creative Commons Attribution license (http://creativecommons.org/licenses/by/4.0/). 